\title{
Tratamiento de un caso complejo de úlceras por incontinencia
}

\author{
Ma José Portillo Gañán ${ }^{(1)}$, Esther Cifuentes Mora(2), Maribel Forteza Gómez ${ }^{(3)}$, Ana Isabel Martínez Asensio(4), Àngels Muñoz \\ Clavero $^{(5)}$, Pilar Ballesteros Aín ${ }^{(6)}$, Beatriz Guerrero Román ${ }^{(6)}$, Laura Arbonés Fincias ${ }^{(5)}$, Àngels Fenández de la Fuente ${ }^{(2)}$ \\ (1) EAP Santa Eulàlia Nord, (2) EAP Castelldefels, ${ }^{\left({ }^{(3)}\right.}$ Smith\&Nephew, ${ }^{(4)}$ EAP Santa Eulàlia Sud, (5) EAP Viladecans 1, (6) EAP Viladecans 2
}

\section{RESUMEN}

Varón, 41 años. Antecedentes personales de interés: parapléjico por espina bífida, hipertensión, insuficiencia venosa crónica y doble incontinencia, con dificultad por parte de la familia para mantener una higiene adecuada.

El paciente presenta en la zona sacra dermatitis del pañal y úlcera profunda de $4 \times 2 \mathrm{~cm}$, situada en pliegue cutáneo cerca del ano.

\section{OBJETIVO}

Mantener la integridad cutánea para evitar la aparición de nuevas lesiones.

Resolución de la úlceras con la máxima eficacia y efectividad Mantener el máximo confort para el paciente.

\section{METODOLOGÍA}

Se realiza limpieza de la úlceras en zona sacra con agua y jabón neutro.

Se aplica crema barrera con óxido de zinc para la protección de la piel perilesional.

En la úlcera y demás lesiones se pauta plata nanocristalina para protegerlas de la bacterias, principalmente fecales. Se cubre con alginato.

Comenzamos las curas en el centro dos veces por semana, asumiendo el familiar realizar las curas en función de la doble incontinencia.

\section{RESULTADOS}

Se inicia el tratamiento el 04/11/2008.

Tras los primeros días de tratamiento ya se apreciaba una mejoría en toda la piel. En la úlcera se pudo observar una disminución del tamaño y un lecho de granulación.

Tras dos meses la lesión está casi cicatrizada y la piel sigue en buenas condiciones. Se decide aplicar en la úlcera colágeno en polvo combinado con hidrogel para estimular la epitelización. Una vez epitelizada la úlcera, se mantuvo crema barrera con óxido de zinc par evitar la aparición de nuevas lesiones

\section{CONCLUSIÓN}

En este caso se utilizaron diferentes dispositivos para la incontinencia (colectores, sonda vesical), no siendo bien tolerados por el paciente y hubo de continuar con la utilización de pañales.

La protección de la piel de toda la zona sacra y genital, con crema barrera de óxido de zinc, la cual disminuye el riesgo de formación de lesiones que en ocasiones son difíciles de evitar, teniendo en cuenta la doble incontinencia del paciente.

La utilización de plata nanocristalina aisló la lesión evitando complicaciones infecciosas.

La combinación de diferentes apósitos de cura en ambiente húmedo junto al colágeno nos ha permitido optimizar la cicatrización de la lesión.

Cambio de superficie en la silla de ruedas, utilizando un cojín antiescaras.
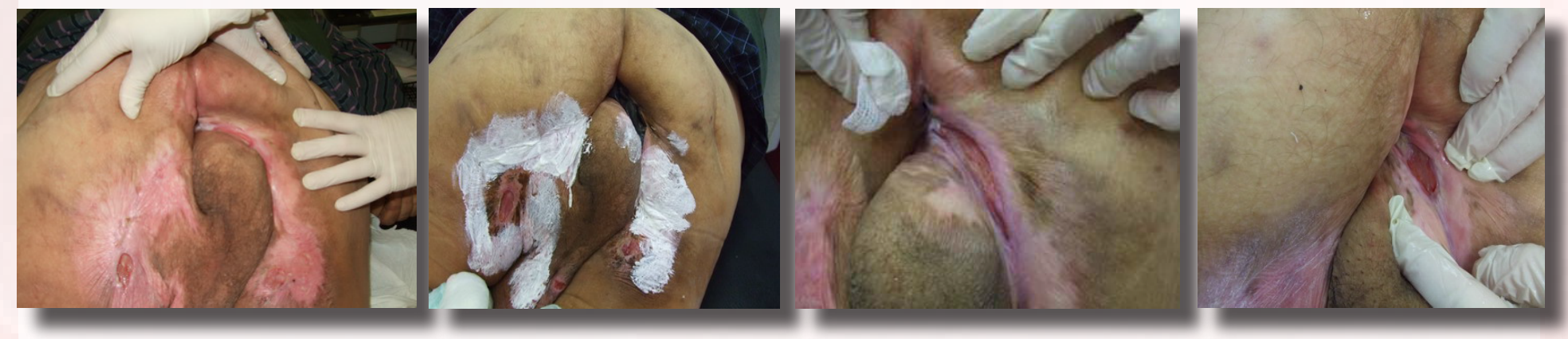